\section{Europe in trouble}

\section{The impending trade dispute with the United States will confirm fears about the new Europe.}

THE European Community seems well on the way to being an obstruction to international amity. That is the chief lesson that will be learned from the foolish dispute with the United States over the import of beef which was institutionalized last Sunday, the first day of the New Year. The most immediate consequence will be to sour the atmosphere in which some kind of compromise must be hammered out on the future of the international agreements that make the world's free trade an engine of beneficent economic change; after the collapse last December of the Montreal negotiations of an extended basis for the General Agreement on Tariffs and Trade (GATT), it was agreed that the participants have only until April to settle their differences.

But the more distant yet more serious consequences of the dispute will be to confirm the impression that the new Europe is bent on being a selfish and restrictive member of the international community, more concerned with its own interests than with the well-being of the whole world, which is what the critics of the European Community have always feared.

It is especially discreditable that this year's trade dispute should spring from what is represented as a scientific issue. Two years ago, the European Community took the view that beef cattle nurtured with the help of bovine growth hormones would yield beef that endangers the health of those who eat it. There appears to be no factual basis for this supposition, but every reason to suppose that the truth is that beef from cattle grown in such a way is identical with what might be called natural beef.

Certainly the European Commission's directive which, from 1 January, bans the sale of beef whose growth has been assisted by the administration of growth hormones is innocent of an objective test for telling now-tainted beef from that whose sale is to be allowed. Instead, those wishing to import beef into Europe have to obtain a certificate from suppliers elsewhere that their cattle have not been fed growth hormones to help them grow more quickly. And there seems no doubt that the motives for the new restrictions on the sale of beef grown with the help of hormones are simply the commission's wish to make European agriculture less efficient than it could be, and thus a less embarrassing charge on European budgets. Briefly, Europe has decided to ban the sale of beef grown with the help of growth hormones because it does not wish to pay European farmers even more than it does at present for the accumulation of unsaleable stocks of European beef. In a rational world, of course, the remedy would have been much simpler; Europe would have reformed its irrational policy on agriculture instead.

\section{Response}

The immediate response of the United States is understandable. With effect from 1 January, retaliatory tariffs will be applied to certain imports of agricultural produce of European origin.

The losers will be of two kinds - consumers in the United States and farmers in the European Community. But there is worse to come. For the European Community now threatens to retaliate against the retaliation instituted by the United States. There is every likelihood that European agriculture ministers, who have many better things to do, will spend their energies in the coming weeks devising lists of agricultural products from the United States to which further restrictions may be applied. The losers, then, will be European consumers, who will have to pay higher prices for goods to which they have become accustomed.
But there is every likelihood that mutual retaliation will escalate, causing people on both sides of the Atlantic to become impoverished and creating a climate in which sensible agreements on the future pattern of free trade cannot be reached.

The prospect of a trade war in agricultural produce between Europe and the United States is, sadly, not the only ominous sign of the way in which modern Europe is tending. In the past few months, the European Commission has responded to the pleadings of European manufacturers by deciding unilaterally that Japanese exports of copying machines and electronic printers are too cheap, and has slapped restrictions on them as well. Japan has rightly decided to appeal against these arbitrary decisions, as GATT procedures allow, but that is a time-consuming and expensive business whose outcome must be uncertain.

Before that corrosive issue can be settled, there will no doubt be other European manufacturers pleading successfully for protection from imports from elsewhere which they consider are too cheap, meaning simply that the prices at which goods are offered for sale are inconveniently and unprofitably low. It may not be long before the manufacturers of civil aircraft, or computing machinery, lodge successful claims that they, too, should be protected from competition from elsewhere. While, in the short run, European manufacturers may enjoy the benefits of markets in which they are the sole suppliers, Europe as a whole will lose both the benefits of competitive prices and of underlying advanced technology.

\section{Gloomy outlook}

The outlook is all the more gloomy because the United States, the most likely target of European protectionism, is now equipped with domestic trade legislation that makes retaliation almost a statutory requirement. While the Reagan administration has steadfastly, over eight years, resisted attempts by the US Congress to protect particular industries from competition from elsewhere, it was forced last year to concede a provision that industries with cause to believe that their competitiveness in export markets is thwarted by foreign restrictions should have a right to demand retaliation. Already there is an awesome queue of claimants. It will be especially difficult for a new administration, needing to plead with Congress on the federal deficit, to keep these domestic demands at bay. In short, there is a serious prospect that the attempt to negotiate a new basis for an extension of GATT's terms of reference will be aborted by a trans-Atlantic trade war extending well beyond the field of agriculture.

If that is what happens in the months ahead, Europe will have to bear the chief responsibility. But, sadly, Europe is not a single entity, but rather a collection of twelve governments with different interests, most of which are narrow interests. Decisions made in Brussels by the European Commission ultimately reflect the way in which particular governments are able successfully to plead their own causes. That is the reason why the common market fully specified by the Treaty of Rome has not yet come about - and why there remain serious dangers that the creation of the single market now planned for 1992 may itself be aborted by strategems not yet conceived. The same narrow view of European affairs offers an explanation as to why it has been so difficult to move towards a rationalization of the agricultural policies that are Europe's self-inflicted burden.

The next few years unfortunately offer narrow-minded European governments too much opportunity for insisting that further moves towards internal free trade must be accompanied by economic protection from outside competition. The ironical result of that will be a Europe which will be self-contained and inward-looking - one in which Europe's founding fathers would prefer not to live. 